\title{
Life History of American Eels from Western Newfoundland
}

\author{
B. M. JeSSOP* \\ Department of Fisheries and Oceans, Bedford Institute of Oceanography, \\ Post Office Box 1006, Dartmouth, Nova Scotia B2Y 4A2, Canada \\ J. C. SHIAO \\ Institute of Oceanography, College of Science, National Taiwan University, Taipei, Taiwan 10617, ROC \\ Y. IIZUKA \\ Institute of Earth Sciences, Academia Sinica, Nankang, Taipei, Taiwan 11529, ROC

\begin{abstract}
Biological data are limited for American eels Anguilla rostrata from the northern portion of the species' geographic range. The biological characteristics of American eels from two sites in western Newfoundland varied by sex, maturation stage, and habitat. Female and male sexually mature (silver) eels from the Castors River were comparable in length range with eels reported from other Newfoundland sites. Female silver eels from the Castors River began their spawning migration at a lower developmental stage for the gonadosomatic index, eye index, and pectoral fin length index than did eels from more southerly sites in eastern Canada and the United States. Annual growth rate declined with increasing age $(r=-0.93, P<$ 0.001). The growth rate at a given age was higher for eels from Muddy Hole (an estuarine habitat at the mouth of Flat Bay Brook) than for those from the Castors River (a freshwater habitat) primarily because growth rate decreased with an increasing proportion of residence in freshwater $(r=-0.74, P<0.001)$. Most eels $(64-$ $72 \%$ ) from both sites had a history of occasional migration between and residence of variable duration in both freshwater and saline water, as determined from otolith strontium : calcium analysis. The mean growth rate of eels that had resided primarily in estuarine waters was 3.2 times greater than the growth of eels that had resided only in freshwater. Additional studies are required to clarify the life history and distributional relations of northern populations of American eels.
\end{abstract}

The American eel Anguilla rostrata is a facultatively catadromous fish (Daverat et al. 2006; Jessop et al. 2008) with an Atlantic continental distribution from at least Central America to central Labrador (Helfman et al. 1987; Scott and Scott 1988). American eels support locally important, seasonal commercial fisheries at the juvenile (yellow) and sexually mature (silver) stages, with the most active fisheries occurring between the Mid-Atlantic states and the upper St. Lawrence River (Eales 1968; Jessop 1997). Elvers (early juveniles) are also fished in several states and provinces, primarily for export to Asia for culture (Jessop 1997, 1998).

American eel stocks have declined in several widely distributed regions of North America (Jessop 1997; Haro et al. 2000). The American eel was designated as a species of special concern by the Committee on the Status of Endangered Wildlife in Canada (COSEWIC 2006) but has not been listed as "at risk" under the Canadian Species At Risk Act. A status review was conducted by the U.S. Fish and Wildlife Service

\footnotetext{
* Corresponding author: jessopb@mar.dfo-mpo.gc.ca
}

Received September 24, 2008; accepted February 3, 2009 Published online June 4, 2009
(USFWS 2005), but the American eel is not presently listed for protection under the U.S. Endangered Species Act (USFWS 2007). One of the difficulties in managing specific fisheries for American eels, let alone their continental population, has been the scarcity and incompleteness of life history data due to their complex, plastic life history and wide geographic range (Haro et al. 2000).

Few studies exist of American eels in Newfoundland; three published studies focus on sites in eastern Newfoundland (Gray and Andrews 1970, 1971; Bouillon and Haedrich 1985), and unpublished studies examine the biology and commercial fishery for eels on the southwestern coast (Brennan 1976) and the general commercial eel fishery (Fletcher and Anderson 1973). The Newfoundland sites are among the most northerly described in the literature. This study examines American eel size and age composition, growth, maturity indices, and growth in relation to residence in freshwater and saltwater habitats at two sites in western Newfoundland, thereby extending the range of available information on the life history of American eels near their northern geographic limit and at a maximum distance from the spawning area. Such analysis may be useful for the examination of life 


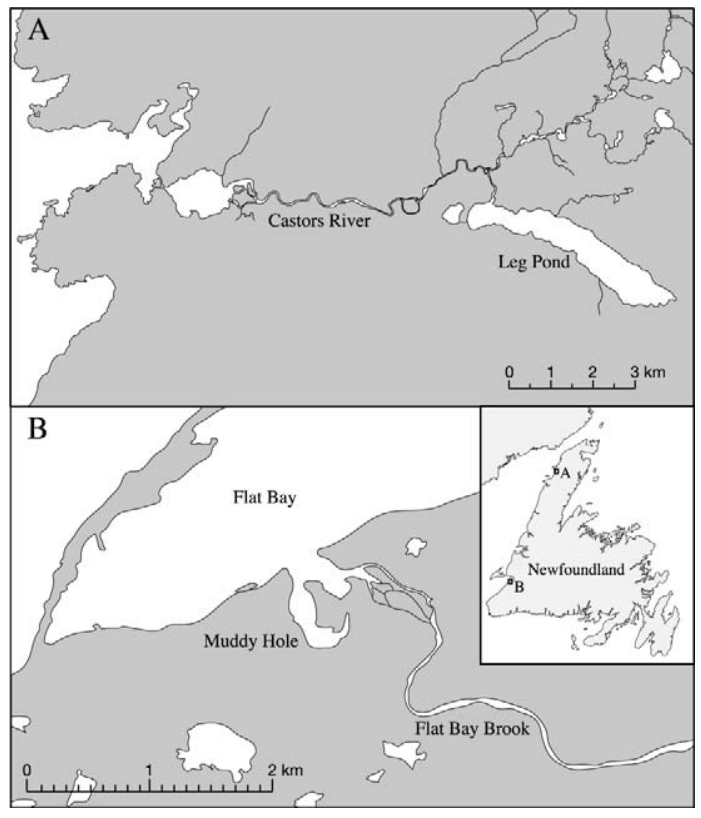

Figure 1.-The mouth and lower reaches of (A) the Castors River and (B) Muddy Hole and Flat Bay Brook. Inset shows location of study sites in western Newfoundland.

history tactics, for effective fisheries management, and for comparison with information from other anguillid eels in the northern hemisphere.

\section{Methods}

Study area.-Muddy Hole, a cove at the mouth of Flat Bay Brook (FBB; $48^{\circ} 24^{\prime} 27^{\prime \prime} \mathrm{N}, 58^{\circ} 34^{\prime} 41^{\prime \prime} \mathrm{W}$ ), and the Castors River $\left(50^{\circ} 55^{\prime} 15^{\prime \prime} \mathrm{N}, 56^{\circ} 57^{\prime} 07^{\prime \prime} \mathrm{W}\right)$ are on the western coast of Newfoundland (Figure 1) and have watershed areas of 635.2 and $544.2 \mathrm{~km}^{2}$, respectively. Water samples taken in the early 1970s indicate that FBB had a pH of 6.5 , standard conductivity of $22 \mu \mathrm{S} /$ $\mathrm{cm}$, and total alkalinity of $4.0 \mathrm{mg} / \mathrm{L}$, while the Castors River had a pH of 7.5 , conductivity of $71 \mu \mathrm{S} / \mathrm{cm}$, and alkalinity of $32.0 \mathrm{mg} / \mathrm{L}$ (Porter et al. 1974). Water samples collected in October 2005 from Muddy Hole, which is a tidal, estuarine cove of about 17 ha in area, indicated a pH of 6.8 and conductivity of $435 \mu \mathrm{S} / \mathrm{cm}$. A $\mathrm{pH}$ of 7.4 and conductivity of $179 \mu \mathrm{S} / \mathrm{cm}$ were recorded in the Castors River at a site about $0.4 \mathrm{~km}$ upstream from the limit of saltwater penetration. Muddy Hole may become entirely freshwater at high FBB discharge levels.

Sampling.-American eels were sampled from commercial fyke-net fisheries at Muddy Hole $(N=$ 57) on 28 September 2005 and at the Castors River on 16 October $2005(N=10)$ and 24 October $2006(N=$ 49) at a site about $11 \mathrm{~km}$ upstream from the river mouth. The unbaited fyke nets each had two wings (typically 10-15 m long, depending upon the site; square knotted or woven mesh with internal stretch of $31.8-38.1 \mathrm{~mm}$ ) attached to a funnel of about $1.5 \mathrm{~m}$ (composed of 25.4-mm stretch mesh) with a $5.5-\mathrm{m}$ long bag (19.1-mm stretch mesh). The minimum legal retention size for American eels is $200 \mathrm{~mm}$. The legal fishing season is from 15 August to 30 November, but the Castors River silver eel fishery typically runs from 15 August to the first week of November, while the Muddy Hole yellow eel fishery runs from late August to the end of October and is believed by the fishers to catch eels coming from salt water to overwinter in the estuary.

Sampling bias.-Sampling American eels by any fishing gear is subject to selection biases, and the catch may not represent the total stock but rather a biological or behavioral group, such as silver or yellow eels (Koops 1980). The representativeness of such sampling depends upon factors such as the time, duration, and procedure of sampling; gear type; and location of fishing (Gulland 1956). Commercial fisheries tend to encompass the duration of any significant migration. Samples were collected during the latter part of the fishery season at each site, but mean length, gonadosomatic index (GSI), and other maturity indices tend to increase over the duration of a silver eel run, with GSI increasing more so than length (Jessop 1987), suggesting that the single-sample values may slightly overestimate the seasonal means. Sample sizes of about 60 eels/site are comparable with or larger than those for many otolith strontium : calcium ( $\mathrm{Sr}: \mathrm{Ca})$ studies but may be insufficient to reliably estimate stock size structure. Sample sizes for describing stock structure depend on the estimator used (e.g., mean or frequency distribution), stock size, size distribution, and lengthfrequency interval used (Miranda 2007). Fewer samples are required to characterize a population mean than a length-frequency distribution, with about 150 samples needed for a mean and 200-400 samples needed for a length-frequency distribution. Gerritsen and McGrath (2006) suggested sample sizes of 10 times the number of length-classes in a sample. The fyke-net bag stretch mesh of $19.1 \mathrm{~mm}$ is sufficient to permit eels less than $200 \mathrm{~mm}$ long to escape as required by law and to progressively retain eels longer than about $220 \mathrm{~mm}$ (Naismith and Knights 1990). Male and female silver American eels migrated at similar times in a Rhode Island stream (Krueger and Oliveira 1999) and may do so in Newfoundland.

Data collection.-Total lengths (TLs; nearest 1.0 $\mathrm{mm}$ ), total body weights (BWs; nearest $0.1 \mathrm{~g}$ ), and gonad weights (GWs; nearest $0.01 \mathrm{~g}$ ) were measured from fresh specimens. Gonads were rinsed with $70 \%$ 
isopropyl alcohol (to firm the tissue before removal), blotted dry, and then weighed. The GSI was calculated as follows:

$$
\mathrm{GSI}=[\mathrm{GW} /(\mathrm{BW}-\mathrm{GW})] \times 100 .
$$

The difference between GSI calculated either excluding or including GW averaged $2.2 \%$ (range $=0.5-5.6 \%$ ) for female silver eels and tended to increase with increasing eel weight. Vertical and horizontal eye diameters and pectoral fin length were measured to the nearest $0.01 \mathrm{~mm}$ by digital calipers. The eye index (EI) was estimated following Pankhurst (1982) as:

$$
\mathrm{EI}=[(\mathrm{Ev}+\mathrm{Eh}) / 4]^{2} \times(\pi / \mathrm{TL}) \times 100,
$$

where Ev and Eh are vertical and horizontal eye diameters $(\mathrm{mm})$ and TL is in millimeters. The pectoral fin index (PFI) was calculated following Durif et al. (2000) as:

$$
\mathrm{PFI}=(\mathrm{PF} / \mathrm{TL}) \times 100,
$$

where PF is pectoral fin length ( $\mathrm{mm})$. Skin pigmentation phase (yellow or silver, following Tesch 1977 and Jessop 1987) was recorded, and sagittal otoliths were extracted for aging and electron-probe microanalysis. Categorization of eels as yellow or silver based primarily on skin pigmentation has no definitive boundary, and categorizations were later compared with morphological measurements, particularly GSI, recognizing that no single measurement can reliably distinguish yellow from silver (migrant) eels (McGrath et al. 2003). No yellow-silver categorizations were changed. Sex was identified by visual inspection following the gonad descriptions of Tesch (1977) and Krueger and Oliveira (1997).

Otoliths were prepared for electron-probe microanalysis, and the $\mathrm{Sr}$ and $\mathrm{Ca}$ concentrations were measured along a transect of the sagittal plane of the otolith from the primordium to the otolith edge as described by Tzeng et al. (1997) and Jessop et al. (2002). The environmental history of each eel was interpreted by examining the temporal pattern of $\mathrm{Sr}: \mathrm{Ca}$ ratios along the otolith transect, with the assumption that the temporal pattern reflects habitat salinity due to the positive relation between otolith $\mathrm{Sr}: \mathrm{Ca}$ ratio and ambient salinity (Tzeng 1996; Kawakami et al. 1998; Secor and Rooker 2000). The percentage of freshwater residence was estimated as the percentage of $\mathrm{Sr}: \mathrm{Ca}$ ratio values of at least $4.0 \times 10^{-3}$ between the elver check and the otolith edge and was considered equivalent to the percentage of freshwater growth $(\%$ FWG; Jessop et al. 2007). After microprobe analysis, the otoliths were repolished and etched with 5\% EDTA to enhance the annuli for aging (Tzeng et al. 1994).
All American eels were aged from photographs of an otolith, at known calibrations, by counting the annuli (translucent zones under reflected light). The distances were measured (nearest $0.001 \mathrm{~mm}$ ) by image analysis software along the longest radius (unless another radius permitted better visualization) from the otolith core to each life stage marker (e.g., metamorphosis check and elver check) and the annuli marking the age in years after the elver stage to the otolith edge. Oliveira (1996) confirmed that otolith increment formation was annual for yellow American eels from a site in the northeastern United States. Annuli were distinguished from supernumerary checks (false annuli) primarily on the basis of their width, optical density, relative positions, and degree of continuity around the otolith circumference (Panfili and Ximénès 1994; Oliveira 1996; Graynoth 1999). Ages were determined by one reader independently three times for each eel and, where differences occurred, a final consensus age was based upon a fourth viewing of the otolith, with awareness of the preceding age estimates. Measurements for back-calculation were based upon the finalized age. Aging precision for the samples from each site was assessed by the coefficient of variation $(\mathrm{CV}=100 \times \mathrm{SD} /$ mean $)$ of the repeated age estimates for each eel, and age bias was evaluated by an age-bias graph (Campana et al. 1995; Campana 2001).

Annual growth rates (GRs) for individual eels from both sites were estimated from back-calculated lengths at age from age 1 onwards, based on the body proportional model (Francis 1990; Jessop et al. 2004). The regression coefficients of the TL-otolith radius $(\mathrm{OR})$ relation $\left(\log _{10} \mathrm{TL}=0.9727 \times \log _{10} \mathrm{OR}+\right.$ 2.6189, where TL and OR are in millimeters; $n=104$, $\left.r^{2}=0.68\right)$ were used to define the following backcalculation equation:

$\log _{10} L_{i}=\left[\left(c+d \log _{10} O_{i}\right) /\left(c+d \log _{10} O_{c}\right)\right] \times \log _{10} L_{c}$, where $L_{i}=$ back-calculated $\mathrm{TL}$ at age $i, L_{c}=\mathrm{TL}$ at capture, $O_{i}=$ otolith radius from primordium to annulus $i, O_{c}=$ otolith radius from primordium to edge, and $c=$ intercept and $d=$ slope from the regression of $\mathrm{TL}$ on $\mathrm{OR}$. Mathematically, $L_{i}$ is a geometric estimate and, thus, was adjusted to an arithmetic estimate following Ricker (1975: 275).

Mean annual continental GRs were estimated for each eel, where

$$
\mathrm{GR}=[(\mathrm{TL}-\mathrm{EL}) / \text { age }] \times 100,
$$

and $\mathrm{EL}=$ mean fresh elver length $(\mathrm{mm})$ at Newfoundland latitudes, calculated as $63.7 \mathrm{~mm}$ from Dutil et al. (1989).

General fish growth and associated life history parameters were estimated for female silver eels from 
TABLE 1.-Sample sizes $(N)$, means ( \pm SD), and ranges (in parentheses) of morphological measurements $(\mathrm{GSI}=$ gonadosomatic index; $\mathrm{EI}=$ eye index; $\mathrm{PFI}=$ pectoral fin index $)$ and age of American eels, by life history stage $(\mathrm{Y}=\mathrm{yellow}, \mathrm{S}=$ silver) and $\operatorname{sex}$ (Ind = indeterminate, $\mathrm{M}=$ male, $\mathrm{F}=$ female), from Muddy Hole $(\mathrm{MH})$ and the Castors River (CR), Newfoundland. Sample sizes were similar for total length (TL) and weight; missing values occurred for some variables. Within columns, pairs of means with $N$ of 7 or more and without a letter in common differ significantly from each other $(P<0.05 ; \mathrm{z}, \mathrm{y}$ within sites; a, b, c, etc. between sites).

\begin{tabular}{|c|c|c|c|c|c|c|c|}
\hline \multirow[b]{2}{*}{ Site } & \multirow[b]{2}{*}{ Stage } & \multirow[b]{2}{*}{ Sex } & \multicolumn{2}{|r|}{$\mathrm{TL}(\mathrm{mm})$} & \multirow{2}{*}{$\frac{\text { Weight }(\mathrm{g})}{\text { Mean } \pm \mathrm{SD} \text { (range) }}$} & \multicolumn{2}{|r|}{ Age (years) } \\
\hline & & & $N$ & Mean $\pm \mathrm{SD}$ (range) & & $N$ & Mean \pm SD (range) \\
\hline \multirow[t]{3}{*}{ MH } & $\mathrm{Y}$ & Ind. & 12 & $360.2 \pm 30.1$ y $(304-400)$ & $69.2 \pm 15.1$ у $(45-93)$ & 11 & $4.4 \pm 0.8$ y $(3-6)$ \\
\hline & $\mathrm{Y}$ & $\mathrm{F}$ & 42 & $440.1 \pm 65.5 \mathrm{z}, \mathrm{bd}(335-662)$ & $141.1 \pm 72.7 \mathrm{z}, \mathrm{a}(61-357)$ & 39 & $6.2 \pm 1.97(3-10)$ \\
\hline & $\mathrm{S}$ & $\mathrm{F}$ & 3 & $590.3 \pm 79.6(500-650)$ & $405.0 \pm 166.1(221-544)$ & 3 & $13.1 \pm 7.5 \mathrm{z}, \mathrm{b}(9-22)$ \\
\hline \multirow[t]{3}{*}{ CR } & $\mathrm{Y}$ & $\mathrm{F}$ & 7 & $512.3 \pm 40.4 \mathrm{y}, \mathrm{c}(464-576)$ & $196.3 \pm 64.5 \mathrm{y}, \mathrm{a}(130-299)$ & 7 & $18.4 \pm 5.8 \mathrm{z}, \mathrm{a}(11-28)$ \\
\hline & $\mathrm{S}$ & M & 3 & $340.0 \pm 16.1(329-361)$ & $50.08 \pm 6.9(43-57)$ & 2 & $9.5 \pm 7.8(4-15)$ \\
\hline & $\mathrm{S}$ & $\mathrm{F}$ & 50 & $663.9 \pm 124.1 \mathrm{z}, \mathrm{a}(431-929)$ & $586.0 \pm 380.6 \mathrm{z}(106-1633)$ & 50 & $19.7 \pm 6.1 \mathrm{z}(8-32)$ \\
\hline
\end{tabular}

the Castors River with the von Bertalanffy growth function (VBGF) adjusted for possible aging error following Cope and Punt (2007). Estimates of the VBGF parameters were estimated both by the standard nonlinear regression (SNL) model and by a random effects (RE) model. Variants of the SNL approach used (1) only the primary age read, (2) the average age of multiple reads, and (3) the median age of multiple reads. Aging error was incorporated into the VBGF parameter estimates using the RE model, with the true ages assumed to have a gamma distribution.

Variables used in statistical analyses (analysis of variance, analysis of covariance [ANCOVA], and correlation) were transformed for analysis as necessary to meet the requirements of parametric statistics. The $\mathrm{BW}$, age, GSI, and GR data were natural logarithm $\left(\log _{e}\right)$ transformed, and \% FWG values were first converted to proportional values and then were arcsine-square-root transformed. Statistical significance was accepted at $P$-values less than 0.05 .

\section{Results}

\section{Length, Weight, and Age Characteristics}

Most biological characteristics differed significantly in mean values between American eels from Muddy Hole and the Castors River and between stages of sexual development and color phase (Table 1). The TL, weight, and age distributions of American eels from Muddy Hole were positively skewed and dominated by smaller (mean $\mathrm{TL}=431.2 \mathrm{~mm}$, range $=304-662 \mathrm{~mm}$; mean weight $=139.8 \mathrm{~g}$, range $=45-544 \mathrm{~g}$ ) and younger eels (mean age $=6.2$ years, range $=3-22$ years), and most $(95 \%)$ of these individuals were yellow eels (Figure 2). In the Castors River, the distributions were platykurtic and extended, with larger (mean TL $=630.2 \mathrm{~mm}$, range $=329-929 \mathrm{~mm}$; mean weight $=513.7 \mathrm{~g}$, range $=43$ $1,633 \mathrm{~g}$ ) and older (mean age $=19.2$ years, range $=4-32$ years) individuals that were mostly $(88 \%)$ silver eels.
In Muddy Hole, eels of indeterminate sex were shorter $(360.2 \mathrm{~mm})$ on average than female yellowstage eels $\left(440.1 \mathrm{~mm}, F_{152}=16.7, P<0.001\right)$, weighed less $\left(69.2 \mathrm{~g}\right.$ versus $141.1 \mathrm{~g}, F_{1,52}=19.0, P<$ 0.001 ), were younger (4.4 years versus 6.2 years, $F_{1,48}$ $=8.4, P=0.006)$, and had a lower GSI (0.34 versus $\left.0.58, F_{1.51}=25.7, P<0.001\right)$ and a lower EI $(3.37$ versus $\left.4.25, F_{1.51}=18.0, P<0.001\right)$. In the Castors River, female yellow eels were significantly shorter
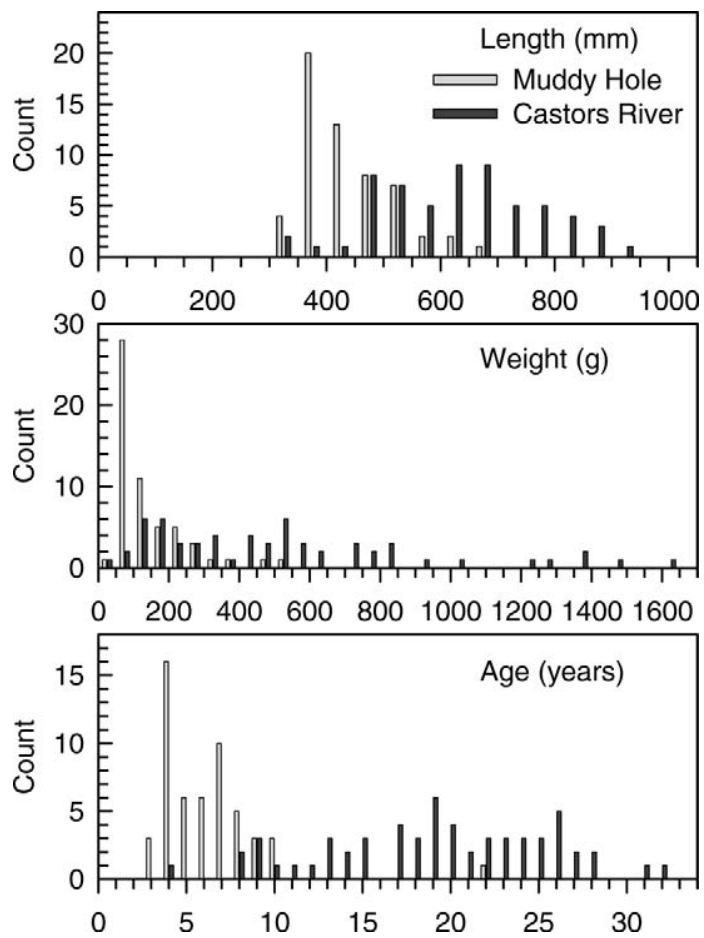

FIGURE 2.-Total length, weight, and age-frequency distributions (both sexes combined; silver and yellow color phases combined) for American eels from two sites in western Newfoundland. 
TABLE 1.-Extended.

\begin{tabular}{|c|c|c|c|c|c|c|}
\hline \multirow[b]{2}{*}{ Site } & \multicolumn{2}{|r|}{ GSI } & \multicolumn{2}{|r|}{ EI } & \multicolumn{2}{|r|}{ PFI } \\
\hline & $N$ & Mean $\pm \mathrm{SD}$ (range) & $N$ & Mean $\pm \mathrm{SD}$ (range) & $N$ & Mean \pm SD (range) \\
\hline \multirow[t]{3}{*}{ MH } & 11 & $0.34 \pm 0.10$ y $(0.19-0.49)$ & 12 & $3.37 \pm 0.39$ у $(2.62-4.16)$ & & \\
\hline & 42 & $0.58 \pm 0.17 \mathrm{z}, \mathrm{c}(0.03-1.03)$ & 41 & $4.25 \pm 0.69 \mathrm{z}, \mathrm{b}(2.84-5.54)$ & & \\
\hline & 3 & $2.24 \pm 1.49(1.21-3.80)$ & 3 & $6.59 \pm 1.36(5.03-7.48)$ & & \\
\hline \multirow[t]{3}{*}{$\mathrm{CR}$} & 7 & $0.81 \pm 0.18$ y,b $(0.61-1.10)$ & 7 & $4.40 \pm 0.89$ y,b (2.69-5.32) & 3 & $3.18 \pm 0.72(2.35-3.64)$ \\
\hline & 3 & $0.63 \pm 0.25(0.38-0.88)$ & 3 & $4.34 \pm 2.30 \mathrm{z}(2.23-7.76)$ & 2 & $3.92 \pm 0.24(3.75-4.09)$ \\
\hline & 50 & $2.23 \pm 1.63 \mathrm{z}, \mathrm{a}(0.48-5.58)$ & 50 & $6.26 \pm 2.03 \mathrm{z}, \mathrm{a}(3.32-11.53)$ & 44 & $4.35 \pm 0.49(3.47-5.35)$ \\
\hline
\end{tabular}

(mean TL $=512.3 \mathrm{~mm}$ ) than female silver eels $(663.9$ $\left.\mathrm{mm}, F_{1,55}=10.2, P=0.002\right)$ and were lighter $(196.3 \mathrm{~g}$ versus $\left.586.0 \mathrm{~g}, F_{1,55}=11.8, P=0.001\right)$, although ages were similar (18.4 years versus 19.7 years, $F_{1,55}=$ $0.14, P=0.71)$. Male silver eels, although few in number, were shorter (mean $=340.0 \mathrm{~mm}$ ), lighter $($ mean $=50.1 \mathrm{~g})$, and younger $($ mean $=9.5$ years $)$ and had a lower GSI (0.63) than female silver eels. Mean GSI values for Castors River female yellow eels (0.81) were significantly lower $\left(F_{1,55}=7.7, P=0.008\right)$ than for female silver eels (2.23), as were EI values (4.4 versus $\left.6.3, F_{1,55}=5.7, P=0.020\right)$. Female yellow eels from Muddy Hole were significantly shorter $\left(F_{1,47}=\right.$ $7.9, P=0.007)$, lighter $\left(F_{1,47}=4.6, P=0.037\right)$, and younger $\left(F_{1,44}=65.6, P<0.0001\right)$ than female yellow eels from the Castors River; the GSI was lower for Muddy Hole female yellow eels $\left(F_{1,47}=9.3, P=\right.$ $0.004)$, but EI values were comparable $\left(F_{1,46}=0.24, P\right.$ $=0.63$ ) between the two groups.

For 53 eels from Muddy Hole, the mean CV for replicate age readings was $4.1 \%$ (median $=0 \%$, range $=$ 0-32.7\%); seven of these eels had a $\mathrm{CV}$ greater than $10 \%$. For 59 eels from the Castors River, the mean CV was $6.2 \%$ (median $=4.0 \%$, range $=0-60.2 \%$ ) and nine of the eels had a CV greater than $10 \%$. Age-bias plots of the replicate age readings versus the base reading for the age composition from each river indicated no major or systematic differences between different age readings and a 1:1 equivalence; the exception was one eel from Muddy Hole with a base age moderately different from the replicate ages that produced a modest deviance from the equivalence line. The consensus re-aging eliminated this bias.

\section{American Eel Growth}

Lengths at age of female American eels estimated from back-calculation varied greatly among and within individuals. Lengths at age for female yellow $(N=39)$ and silver $(N=3)$ eels from Muddy Hole were significantly greater than those for female yellow $(N=$ $7)$ and silver $(N=50)$ eels from the Castors River based on the general nonoverlap of the $95 \%$ confidence intervals (CIs) for lengths at age; however, for ages 1-3 and $8-9$, the interpretation was equivocal due to low sample size ( $N=12$ and 7 , respectively) at those ages for Muddy Hole (Figure 3). Annual growth increments derived from the length-at-age estimates declined with age and were significantly higher over the available age range at Muddy Hole than at the Castors River (Figure 4).

The average GR of female American eels from the Newfoundland study sites declined significantly $(N=$ 99, $r=-0.93, P<0.001$ ) with increasing age (Figure $5)$. The slopes of the relation did not differ significantly (ANCOVA: $F_{1,95}=0.77, P=0.34$ ) between sites nor did the adjusted mean GRs $\left(F_{1,96}=0.46, P=0.50\right)$, which permitted pooling of the data across sites. However, the grand mean GR was significantly lower

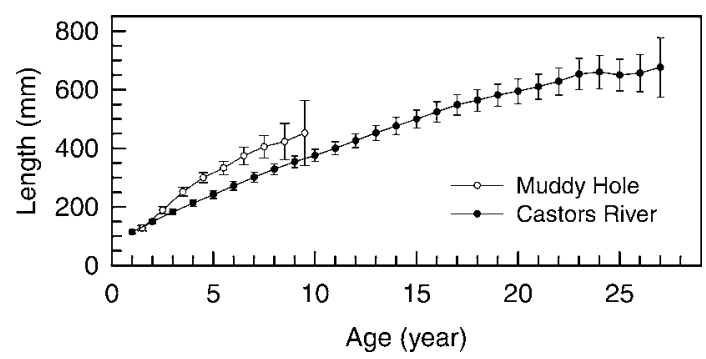

FIGURE 3.-Mean ( $\pm 95 \%$ confidence interval $[\mathrm{CI}])$ backcalculated total lengths at age for indeterminate (sex unknown) and female (silver and yellow color phases combined) American eels from two sites in western Newfoundland. Lengths at age from Muddy Hole have been shifted upwards by 0.5 years to avoid overlap of CIs. Number at age declines from 57 to 6 eels for the Castors River and from 42 to 7 eels for Muddy Hole. 


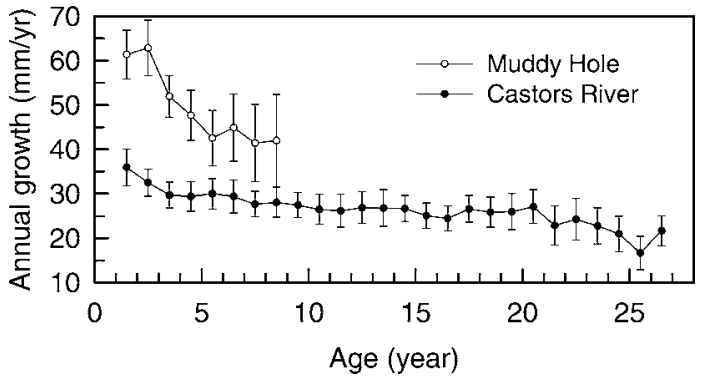

FIGURE 4.-Mean $( \pm 95 \%$ confidence interval $[\mathrm{CI}])$ annual growth increment (mm/year) for female (silver and yellow color phases combined) American eels from two sites in western Newfoundland. Number at age declines from 57 to 6 eels for the Castors River and from 42 to 7 eels for Muddy Hole.

(31.8 $\mathrm{mm} /$ year) for the mostly silver eels from the Castors River than for the mostly yellow eels (65.0 $\mathrm{mm} /$ year $)$ from Muddy Hole $\left(F_{1,97}=131.3, P<0.001\right)$ because of the large difference in age distributions between sites (Castors River mean age $=19.6$ years, Muddy Hole mean age $=6.7$ years) and the intrinsic difference in GR between sites.

Comparisons of the mean estimates of the VBGF parameters were either not significantly different or no conclusion could be made based on the overlap of the 95\% CIs and the inclusion or exclusion of a given mean from the comparison CI (Table 2). Plots of the estimated lengths at age for the different VBGF models differed at younger ages but became very similar at older ages. Thus, at age 0 the smallest estimated TL (101 $\mathrm{mm}$ ) from the SNL (mean age) model was 50\% less than the largest TL (152 mm) from the SNL (single age) model, but by age 5 the difference was $5 \%$ and decreased steadily thereafter until age 32, when the difference was less than $1 \%$. The CVs for TL and age were essentially constant.

\section{Habitat Effects on Growth}

The mean \% FWG of female American eels varied significantly between sites (Muddy Hole $=30.2 \%$, range $=1.2-91.2 \%$; Castors River $=70.0 \%$, range $=$ 16.0-100.0\%; $t=8.34$, df $=97, P<0.001$ ), with skewed frequency distributions at each site (Figure 6). Of the 57 female silver eels from the Castors River, $72 \%$ showed a history of interhabitat migration, as did $98 \%$ of the 42 female yellow and silver eels from Muddy Hole. The average GR declined significantly $(N$ $=99, r=-0.74, P<0.001)$ with increasing residence period in freshwater $(\% \mathrm{FWG})$ for both sites combined (Figure 7) and for each site (Muddy Hole: $N=42, r=$ $-0.61, P<0.001$; Castors River: $N=57, r=-0.50, P$ $<0.001)$. The slopes of the relation did not differ

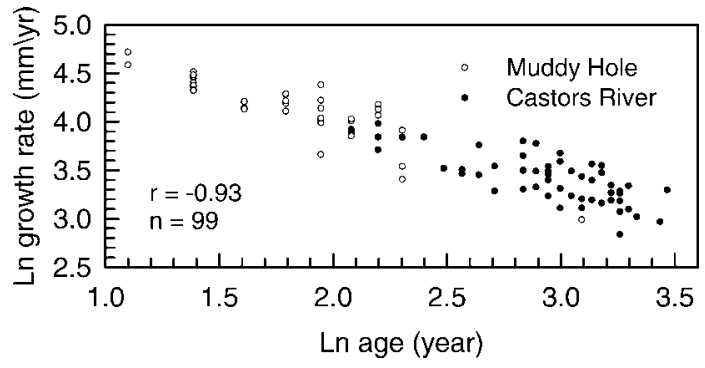

FIGURE 5.-Relation between mean $\log _{e}$ transformed growth rate (GR; mm/year) and $\log _{e}$ transformed age (years) for female (silver and yellow color phases combined) American eels from two sites in western Newfoundland $(N$ $=99$ eels, GR range $=11.8-111.8 \mathrm{~mm} /$ year, age range $=3-32$ years).

significantly $\left(F_{1,95}=3.82, P=0.054\right)$, but the adjusted mean GR was significantly higher for eels from Muddy Hole than from the Castors River $\left(F_{1,96}=43.9, P<\right.$ 0.001 ), due partly to the significant difference between sites in \% FWG. However, the distributional range and overlap of the data from each site are such that pooling of the data was deemed reasonable for evaluating the correlation between GR and \% FWG. The relation between GR and \% FWG was $\log _{e} \mathrm{GR}=4.4966-$ $[0.9120 \times($ arcsine-square root-transformed $\% \mathrm{FWG})]$. Based on this relationship, female eels with $0 \%$ FWG had a mean estimated GR that was 3.2 times that of eels with $100 \%$ FWG.

\section{Discussion}

\section{Primary Biological Characteristics}

The lengths, weights, and ages of American eels from two sites in western Newfoundland varied by sex, maturation stage, and habitat, primarily because the eels from Muddy Hole were mostly yellow juvenile eels and those from the Castors River were mostly silver maturing eels. Such differences due to life stage and geographic variability in habitat productivity and environmental conditions are well documented (Tesch 1977; Helfman et al. 1987; Vøllestad 1992), including those for rivers in Newfoundland (Gray and Andrews 1971; Bouillon and Haedrich 1985).

Yellow female American eels from Muddy Hole began sexual differentiation at lengths comparable with those from other northern rivers (Dolan and Power 1977; Jessop 1987; Krueger and Oliveira 1999). However, relatively large, undifferentiated eels in Muddy Hole were more common than in the more southern rivers, perhaps reflecting the difficulty of visual identification of sex relative to the histological methods used in the latter studies (sex differentiation occurs before macroscopic differentiation is detectable; 
TABLE 2.-Estimates of mean ( $\pm 95 \%$ confidence interval $[\mathrm{CI}])$ von Bertalanffy growth model parameters for female silver $(N$ $=50)$ and yellow $(N=7)$ American eels from the Castors River, Newfoundland, fitted by standard nonlinear methods (SNL) with the mean or median of three (all ages similar; $N=9$ ) and four (consensus age included; $N=48$ ) otolith age readings, SNL with the consensus (single) age, or a random effects (RE) model that assumes a gamma population distribution $\left(L_{\infty}=\right.$ asymptotic average total length, $k=$ growth coefficient, $t_{0}=$ theoretical age at which length is zero, $\mathrm{CV}=$ coefficient of variation).

\begin{tabular}{|c|c|c|c|c|c|c|c|c|}
\hline \multirow[b]{2}{*}{ Method } & \multicolumn{2}{|c|}{$L_{\infty}(\mathrm{mm})$} & \multicolumn{2}{|c|}{$k\left(\right.$ year $\left.^{-1}\right)$} & \multicolumn{2}{|c|}{$t_{0}$ (years) } & \multicolumn{2}{|c|}{ Error CV } \\
\hline & Mean & $95 \% \mathrm{CI}$ & Mean & $95 \% \mathrm{CI}$ & Mean & $95 \% \mathrm{CI}$ & Length & Age \\
\hline SNL (mean age) & 815.4 & $796.2-834.6$ & 0.083 & $0.074-0.091$ & -1.60 & -2.35 to -0.84 & 0.10 & \\
\hline SNL (median age) & 830.9 & $808.4-853.5$ & 0.075 & $0.067-0.083$ & -2.41 & -3.26 to -0.56 & 0.10 & \\
\hline SNL (single age) & 845.2 & $820.8-869.7$ & 0.070 & $0.062-0.077$ & -2.84 & -3.71 to -0.96 & 0.10 & \\
\hline RE gamma & 826.2 & $794.0-858.5$ & 0.076 & $0.065-0.088$ & -1.90 & -3.06 to -0.75 & 0.14 & 0.09 \\
\hline
\end{tabular}

Colombo and Grandi 1996) or reflecting an increase in the mean size at which maturation occurs at more northerly latitudes. Undifferentiated and differentiated yellow eels from Muddy Hole overlapped considerably in length distribution, a common observation (Dolan and Power 1977; Helfman et al. 1987; Krueger and Oliveira 1999), indicating that sexual differentiation begins over a range of lengths. Sex differentiation may occur at a critical size rather than age in European eels A. anguilla (Melia et al. 2006), which is consistent with the observation that American eels exceed $150 \mathrm{~mm}$ before differentiation begins (Dolan and Power 1977) and that differentiation may be well underway at lengths of 200-300 mm (Dolan and Power 1977; Helfman et al. 1987).

Female silver eels from the Castors River began their spawning migration at a lower developmental stage for GSI, EI, and PFI than did eels from more southerly sites in eastern Canada and the United States (Wenner and Musick 1974; Jessop 1987; Cottrill et al. 2002; McGrath et al. 2003; Verreault et al. 2003). The lower GSI, EI, and PFI of migrating female silver eels from the more northerly Castors River may reflect differences in those values between eels of smaller (Castors River) and larger size (e.g., Gulf of St. Lawrence) due

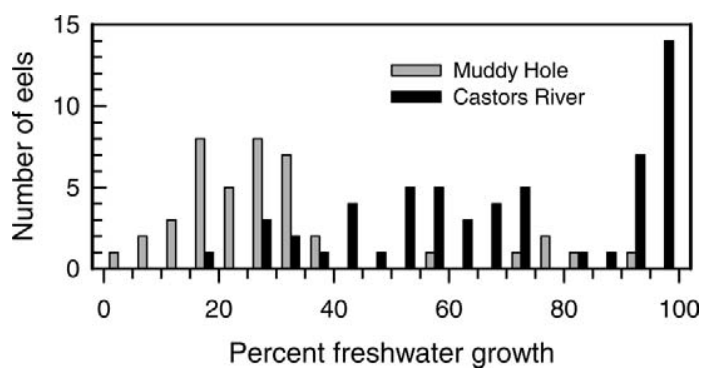

FIGURE 6.-Frequency distribution of percent freshwater growth (residence) in female (silver and yellow color phases combined) American eels from two sites in western Newfoundland (total $N=99$ eels; Castors River $N=57$, Muddy Hole $N=42$ ). to their positive relation with TL, but comparison with eels of similar size show index differences that are sufficiently large to be real. A progressive increase also occurs in maturation indices (GSI, EI, and PFI) during migration, with consequent effect on the comparison of maturation indices among sites due to the timing of sampling. Minor differences in index values, particularly GSI, may result from different methods of estimation among studies. A lower degree of sexual maturation at the onset of the spawning migration in more northerly eel stocks and the additional developmental period available during their longer marine migration may permit fish from different latitudes to reach the spawning ground at approximately similar times and reproductive condition (Wenner 1973; Helfman et al. 1987). No single maturation index is sufficient to accurately classify migrant, sexually maturing, and nonmigrant eels, and even a suite of indices has some misclassification error (Cottrill et al. 2002; McGrath et al. 2003).

The low abundance and small size of male silver American eels in the Castors River sample are consistent with the generally low abundance and

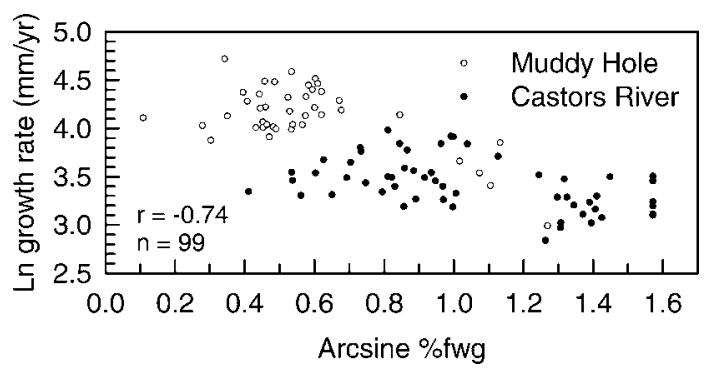

FIGURE 7.--Relation between $\log _{e}$ transformed mean growth rate (GR; mm/year) and arcsine-transformed percentage of freshwater growth (residence; \% FWG) for female (silver and yellow color phases combined) American eels from two sites in western Newfoundland (total $N=99$ eels, Castors River $N=57$, Muddy Hole $N=42$; GR range $=11.8-111.8$ $\mathrm{mm} /$ year, \% FWG range $=1.2-100 \%$ ). 
typically small lengths $(<400 \mathrm{~mm})$ of males at northern latitudes (Helfman et al. 1987; Jessop 1987; Krueger and Oliveira 1999), although substantial numbers of male eels have been found in some rivers in the northeastern United States where eel densities are locally high (Krueger and Oliveira 1999; Oliveira and McCleave 2000). The low mean GSI of male silver eels from the Castors River and from the Medway River, Nova Scotia, (Jessop 1987) is consistent with the low (typically $<1.0$ ) GSI values for other male temperate anguillid eels (Durif et al. 2005; Kotake et al. 2005).

\section{America Eel Growth}

American eels from Muddy Hole grew significantly faster and had a higher proportion of interhabitat migration than did eels from the Castors River, probably because the former site is estuarine and the latter is freshwater (Jessop et al. 2008). Yellow eels both overwinter in the muddy bottom of Muddy Hole and migrate upstream in autumn into $\mathrm{FBB}$ to overwinter and may migrate downstream in spring, presumably to feed in estuarine waters (Brennan 1976). Temperate anguillid eels grow more rapidly in estuarine and marine habitats than in freshwater habitats, perhaps because of higher productivity, greater food availability, and lower metabolic costs in estuarine and marine waters than in freshwater (Fernández-Delgado et al. 1989; Jessop et al. 2004, 2008; Kotake et al. 2005; Melia et al. 2006), but the degree of difference is moderated by the degree of interhabitat migration and residence. The annual length increment and average GR declined with increasing age, as is typical for temperate anguillid eels, but variability was high (Poole and Reynolds 1996; Svedäng et al. 1996; Tzeng et al. 2000; Jessop et al. 2004).

Size rather than age may be the primary factor inducing maturation and migration in temperate anguillid eels, with rapid growth prompting achievement of a critical size and consequent migration at an earlier age (Rossi and Colombo 1979; Helfman et al. 1987). The constrained length composition of male silver eels, absence of a latitudinal cline in size at migration, and increase in age with increasing latitude support a hypothesis of a time-minimizing life history strategy for male American eels such that males migrate at the minimum size sufficient to accomplish the spawning migration, while female American eels have a life history strategy that maximizes size (and fecundity) at maturity at the expense of a longer continental growth period and consequent increased probability of mortality (Helfman et al. 1987; Oliveira 1999). However, Svedäng et al. (1996) concluded that female maturation occurs at neither a critical size nor a critical age and proposed a time-minimizing hypothesis for female European eel maturation based on the observation of a negative relation between age at maturation and GR for Swedish European eel stocks from a limited latitudinal range. Female American eels also showed a negative relation between age at maturation and GR. Because of the absence of a significant relation between age at migration and latitude and the presence of a negative correlation between GR and latitude for female American eels, Oliveira (1999) suggested that factors other than growth may influence female size at migration and that maturation may be optimized over a continuum between a time-minimizing strategy and a sizemaximizing strategy according to habitat conditions so that optimal size and condition are reached in minimal time. A shorter growing season and reduced habitat productivity at northern latitudes increase the time to reach the optimal size for migration. Growth rate is a crude estimate of the physiological status of fish, and the onset of maturation is closely related to the accumulation of the lipid energy stores necessary for full gonadal development (Svedäng et al. 1996) and the completion of the long-distance migration to the spawning ground (Larsson et al. 1990; Van Ginneken et al. 2005). Whatever mechanism is in place, anguillid eels have evolved sex-specific growth strategies and rates that enable them to successfully adapt to a wide range of habitats over a large geographic range (Oliveira and McCleave 2002).

The values for the RE model of the VBGF are preferred because they explicitly account for aging error and provide parameter values that are generally more accurate and precise (Cope and Punt 2007). The mean asymptotic length $\left(L_{\infty}\right)$ value for Castors River female silver eels was larger than the majority of lengths at migration, indicating that most American eels migrated at lengths less than their theoretical average length at maximum age, which is consistent with the observation that most eels migrate at less than the maximum observed age (Poole and Reynolds 1996). The accuracy and precision of VBGF parameter estimates improve with increasing sample size, and estimates of $L_{\infty}$ and theoretical age at a length of zero $\left(t_{0}\right)$ depend greatly on the extremes of the length and age distributions. The sample size for age (and length) is relatively low, potentially biasing the VBGF parameter estimates, but the extremes of the length and age distributions for female silver eels compare well with those at other Newfoundland sites (Gray and Andrews 1971; Bouillon and Haedrich 1985).

\section{Habitat Effects on Growth}

Some American eels from Newfoundland, near the northern limit of the species' range, may spend varying 
proportions of their lives in either freshwater or estuarine and marine waters and may engage in occasional interhabitat migration. Juvenile eels may inhabit both freshwater and saline habitats (Helfman et al. 1987) and make periodic seasonal movements between freshwater and estuarine areas (Smith and Saunders 1955; Medcof 1969; Jessop 1987). Recent studies have proposed, based on otolith $\mathrm{Sr}: \mathrm{Ca}$ ratio analysis, a general categorization of eel residency composed of freshwater, estuarine, marine, and interhabitat migrant groups (Daverat et al. 2006; Jessop et al. 2008). Consequently, temperate-zone anguillid eels can be considered facultatively catadromous with a variable euryhaline migratory component. The proportions (or abundance) of river system or regional eel stocks that make up each habitat residence group are generally unknown and may vary substantially among rivers (Haro et al. 2000; Jessop et al. 2008), but knowledge of these proportions is of great importance to the evaluation of stock status and fishery management. The proportion of residence time in freshwater or saline waters may significantly influence the value and variability of American eel GR, size, and age composition (Jessop et al. 2004; Lamson 2006; this study), with substantial implications for understanding the life history of American eels and other temperatezone eels. The occurrence of interhabitat migrant eels may, as suggested by Krueger and Oliveira (1999), even affect sex ratio if interhabitat migration changes local density sufficiently to influence the environmental effect on sex determination.

Overall, the biological data available from the extremes of the American eel's geographic range are insufficient to test many plausible hypotheses, and further research is required.

\section{Acknowledgments}

We thank M. Feigenbaum and M. Campbell for provision of the Newfoundland American eels and for the use of sample processing facilities at South Shore Trading Company Ltd. We are grateful to D. Cairns for comments on the draft manuscript.

\section{References}

Bouillon, D. R., and R. L. Haedrich. 1985. Growth of silver eels (Anguilla rostrata) in two areas of Newfoundland. Journal of Northwest Atlantic Fishery Science 6:95-100.

Brennan, M. 1976. The biology of Anguilla rostrata, with reference to the commercial fishery. Master's thesis, McGill University, Montreal.

Campana, S. E. 2001. Accuracy, precision and quality control in age determination, including a review of the use and abuse of age validation methods. Journal of Fish Biology 59:197-242.

Campana, S. E., M. C. Annand, and J. I. McMillan. 1995.
Graphical and statistical methods for determining the consistency of age determination. Transactions of the American Fisheries Society 124:131-138.

Colombo, G., and G. Grandi. 1996. Histological study of the development and sex differentiation of the gonad in the European eel. Journal of Fish Biology 48:493-512.

Cope, J. M., and A. E. Punt. 2007. Admitting ageing error when fitting growth curves: an example using the von Bertalanffy growth function with random effects. Canadian Journal of Fisheries and Aquatic Sciences 64:205218.

COSEWIC (Committee on the Status of Endangered Wildlife in Canada). 2006. Status Report-American eel. COSEWIC. Available: www.sararegistry.gc.ca. (June 2008).

Cottrill, R. A., R. S. McKinley, and G. V. Der Kraak. 2002. An examination of utilizing external measures to identify sexually maturing female American eels, Anguilla rostrata, in the St. Lawrence River. Environmental Biology of Fishes 65:271-287.

Daverat, F., K. E. Limburg, I. Thibault, J. C. Shiao, J. J. Dodson, F. Caron, W.-N. Tzeng, Y. Iizuka, and H. Wickström. 2006. Phenotypic plasticity of habitat use by three temperate eel species, Anguilla anguilla, A. japonica, and A. rostrata. Marine Ecology Progress Series 308:231-241.

Dolan, J. A., and G. Power. 1977. Sex ratio of American eels, Anguilla rostrata, from the Matamek River system, Quebec, with remarks on problems in sexual identification. Journal of the Fisheries Research Board of Canada 34:294-299.

Durif, C., S. Dufour, and P. Elie. 2005. The silvering process of Anguilla anguilla: a new classification from the yellow resident to the silver migrating stage. Journal of Fish Biology 66:1025-1043.

Durif, C., P. Elie, S. Dufour, J. Marchelidon, and B. Vidal. 2000. Analysis of morphological and physiological parameters during the silvering process of the European eel (Anguilla anguilla) in the lake of Grand-Lieu (France). Cybium 24:63-74.

Dutil, J. D., M. Michaud, and A. Giroux. 1989. Seasonal and diel patterns of stream invasion by American eels (Anguilla rostrata) in the northern Gulf of St. Lawrence. Canadian Journal of Zoology 67:182-188.

Eales, J. G. 1968. The eel fisheries of eastern Canada. Fisheries Research Board of Canada Bulletin 166.

Fernández-Delgado, C., J. A. Hernando, M. Herrera, and M. Bellido. 1989. Age and growth of yellow eels, Anguilla anguilla, in the estuary of the Guadalquivir River (southwest Spain). Journal of Fish Biology 34:561-570.

Fletcher, G. L., and T. Anderson. 1973. A quantitative survey of the American eel (Anguilla rostrata) in Newfoundland. Marine Sciences Research Laboratory, Memorial University, Final Progress Report, St. John's, Newfoundland, Canada.

Francis, R. I. C. C. 1990. Back-calculation of fish length: a critical review. Journal of Fish Biology 36:561-570.

Gerritsen, H. D., and D. McGrath. 2006. Precision estimates and suggested sample sizes for length-frequency data. U.S. National Marine Fisheries Service Fishery Bulletin 106:116-120.

Gray, R. W., and C. W. Andrews. 1970. Sex ratios of the American eel (Anguilla rostrata (LeSueur)) in New- 
foundland waters. Canadian Journal of Zoology 48:483487.

Gray, R. W., and C. W. Andrews. 1971. Age and growth of the American eel (Anguilla rostrata (LeSueur)) in Newfoundland waters. Canadian Journal of Zoology 49:121-128.

Graynoth, E. 1999. Improved otolith preparation, ageing and back-calculation techniques for New Zealand freshwater eels. Fisheries Research 42:137-146.

Gulland, J. A. 1956. The study of fish populations by the analysis of commercial catches. Rapports et ProcèsVerbaux des Réunions, Conseil International pour l'Exploration de la Mer 140:21-27.

Haro, A., W. Richkus, K. Whalen, A. Hoar, W.-D. Busch, S. Lary, T. Brush, and D. Dixon. 2000. Population decline of the American eel. Fisheries 25(9):7-16.

Helfman, G. S., D. E. Facey, L. S. Hales, Jr., and E. L. Bozeman, Jr. 1987. Reproductive ecology of the American eel. Pages 42-56 in M. J. Dadswell, R. J. Klauda, C. M. Moffitt, R. L. Saunders, R. A. Rulifson, and J. E. Cooper, editors. Common strategies of anadromous and catadromous fishes. American Fisheries Society, Symposium 1, Bethesda, Maryland.

Jessop, B. M. 1987. Migrating American eels in Nova Scotia. Transactions of the American Fisheries Society 116:161170.

Jessop, B. M. 1997. An overview of European and American eel stocks, fisheries, and management issues. Canadian Technical Report of Fisheries and Aquatic Sciences 1296:6-20.

Jessop, B. M. 1998. The management of, and fishery for, American eel elvers in the Maritime Provinces, Canada. Bulletin Français de la Pêche et de la Pisciculture 349:103-116.

Jessop, B. M., D. K. Cairns, I. Thibault, and W. N. Tzeng. 2008. Life history of American eel Anguilla rostrata: new insights from otolith microchemistry. Aquatic Biology 1:205-216.

Jessop, B. M., J. C. Shiao, Y. Iizuka, and W. N. Tzeng. 2002. Migratory behaviour and habitat use by American eels Anguilla rostrata as revealed by otolith microchemistry. Marine Ecology Progress Series 233:217-229.

Jessop, B. M., J. C. Shiao, Y. Iizuka, and W. N. Tzeng. 2004. Variation in the annual growth, by sex and migration history, of silver American eels Anguilla rostrata. Marine Ecology Progress Series 272:231-244.

Jessop, B. M., J. C. Shiao, Y. Iizuka, and W. N. Tzeng. 2007. Effects of inter-habitat migration on the evaluation of growth rate and habitat residence of American eels Anguilla rostrata. Marine Ecology Progress Series 342:255-263.

Kawakami, Y., N. Mochioka, K. Morishita, T. Tajima, H. Nakagawa, H. Toh, and A. Nakazono. 1998. Factors influencing otolith strontium/calcium ratios in Anguilla japonica elvers. Environmental Biology of Fishes 52:299-303.

Koops, H. 1980. Sampling eels. European Inland Fisheries Advisory Committee Technical Paper 33:124-136.

Kotake, A., A. Okamura, Y. Yamada, T. Utoh, T. Arai, M. J. Miller, H. P. Oka, and K. Tsukamoto. 2005. Seasonal variation in the migratory history of the Japanese eel
Anguilla japonica in Mikawa Bay, Japan. Marine Ecology Progress Series 293:213-221.

Krueger, W. H., and K. Oliveira. 1997. Sex, size, and gonad morphology of silver American eels Anguilla rostrata. Copeia 1997:415-420.

Krueger, W. H., and K. Oliveira. 1999. Evidence for environmental sex determination in the American eel, Anguilla rostrata. Environmental Biology of Fishes 55:381-389.

Lamson, H. M. 2006. Movement patterns and growth of American eels (Anguilla rostrata) between salt and fresh water, based on otolith microchemistry. Master's thesis, University of New Brunswick, Fredericton, Canada.

Larsson, P., S. Hamrin, and L. Okla. 1990. Fat content as a factor inducing migratory behavior in the eel (Anguilla anguilla L.) to the Sargasso Sea. Naturwissenschaften 77:488-490.

McGrath, K. J., J. Bernier, S. Ault, J.-D. Dutil, and K. Reid. 2003. Differentiating downstream migrating American eels Anguilla rostrata from resident eels in the St. Lawrence River. Pages 315-327 in D. A. Dixon, editor. Biology, management, and protection of catadromous eels. American Fisheries Society, Symposium 33, Bethesda, Maryland.

Medcof, J. C. 1969. Fishermen's reports of freshwater and saltwater migrations of Nova Scotia eels (Anguilla rostrata). Canadian Field-Naturalist 83:132-138.

Melia, P., D. Bevacqua, A. J. Crivelli, J. Panfili, G. A. De Leo, and M. Gatto. 2006. Sex differentiation of the European eel in brackish and freshwater environments: a comparative analysis. Journal of Fish Biology 69:1228-1235.

Miranda, L. E. 2007. Approximate sample sizes required to estimate length distributions. Transactions of the American Fisheries Society 136:409-415.

Naismith, I. A., and B. Knights. 1990. Studies of sampling methods and techniques for estimating populations of eels, Anguilla anguilla L. Aquaculture and Fisheries Management 21:357-367.

Oliveira, K. 1996. Field validation of annular growth rings in the American eel Anguilla rostrata, using tetracyclinemarked otoliths. U.S. National Marine Fisheries Service Fishery Bulletin 94:186-189.

Oliveira, K. 1999. Life history characteristics and strategies of the American eel, Anguilla rostrata. Canadian Journal of Fisheries and Aquatic Sciences 56:795-802.

Oliveira, K., and J. D. McCleave. 2000. Variation in population and life history traits of the American eel, Anguilla rostrata, in four rivers in Maine. Environmental Biology of Fishes 59:141-151.

Oliveira, K., and J. D. McCleave. 2002. Sexually different growth histories of the American eel in four rivers in Maine. Transactions of the American Fisheries Society 131:203-211.

Panfili, J., and M. C. Ximénès. 1994. Évaluation de l'âge et de la croissance de l'anguille Européen (Anguilla anguilla L.) en milieu continental: méthodologies, validation, application en Méditerranée et comparaisons en Europe. [Age and growth estimation of the European eel (Anguilla anguilla L.) in continental waters: methodology, validation, application in Mediterranean area and comparisons in Europe.] Bulletin Français de la Pêche et de la Pisciculture 335:43-66. 
Pankhurst, N. W. 1982. Relation of visual changes to the onset of sexual maturation in the European eel Anguilla anguilla (L.). Journal of Fish Biology 21:127-140.

Poole, W. R., and J. D. Reynolds. 1996. Growth rate and age at migration of Anguilla anguilla. Journal of Fish Biology 48:633-642.

Porter, T. R., L. G. Riche, and G. R. Traverse. 1974. Catalogue of rivers in insular Newfoundland. Resource Development Branch, Newfoundland Region, Data Report Series Number New/D-74-9, volume C, Newfoundland, Canada.

Ricker, W. E. 1975. Computations and interpretation of biological statistics of fish populations. Fisheries Research Board of Canada Bulletin 191.

Rossi, R., and G. Colombo. 1979. Some observations on age, sex, and growth of silver eels (Anguilla anguilla L.) in North Adriatic lagoons. Rapports et Procès-Verbaux des Rèunions, Conseil International pour l'Exploration de la Mer 174:64-69.

Scott, W. B., and M. G. Scott. 1988. Atlantic fishes of Canada. Canadian Bulletin Fisheries and Aquatic Sciences 219.

Secor, D. H., and J. R. Rooker. 2000. Is otolith strontium a useful scalar of life cycles in estuarine fishes? Fisheries Research 46:359-371.

Smith, M. W., and J. W. Saunders. 1955. The American eels in certain fresh waters of the Maritime Provinces of Canada. Journal of the Fisheries Research Board of Canada 12:238-269.

Svedäng, H., E. Neuman, and H. Wickström. 1996. Maturation patterns in female European eel: age and size at the silver eel stage. Journal of Fish Biology 48:342-351.

Tesch, F.-W. 1977. The eel—biology and management of anguillid eels. Chapman and Hall, London.

Tzeng, W. N. 1996. Effects of salinity and ontogenetic movements on strontium: calcium ratios in the otoliths of Japanese eel, Anguilla japonica Temminck and Schlegel. Journal of Experimental Marine Biology and Ecology 199:111-122.

Tzeng, W. N., H. R. Lin, C. H. Wang, and S. N. Xu. 2000. Differences in size and growth rates of male and female migrating Japanese eels in Pearl River, China. Journal of Fish Biology 57:1245-1253.

Tzeng, W. N., K. P. Severin, and H. Wickström. 1997. Use of otolith microchemistry to investigate the environmental history of European eel Anguilla anguilla. Marine Ecology Progress Series 149:73-81.

Tzeng, W. N., H. F. Wu, and H. Wickström. 1994. Scanning electron microscope analysis of annulus microstructure in otolith of European eel, Anguilla anguilla. Journal of Fish Biology 45:479-492.

USFWS (U.S. Fish and Wildlife Service). 2005. Progress Report: the American Eel Status Review. USFWS. Available: www.fws.gov. (June 2008).

USFWS. 2007. Endangered and threatened wildlife and plants; 12-month finding on a petition to list the American eel as threatened or endangered. Federal Register 72: 22(2 February 2007):4967-4997. Available: www.archives.gov. (August 2008).

Van Ginneken, V., E. Antonissen, U. K. Müller, R. Booms, E. Eding, J. Verreth, and G. Van den Thillart. 2005. Eel migration to the Sargasso: remarkably high swimming efficiency and low energy costs. Journal of Experimental Biology 208:1329-1335.

Verreault, G., P. Pettigrew, R. Tardif, and G. Pouliot. 2003. The exploitation of the migrating silver American eel in the St. Lawrence River estuary, Québec, Canada. Pages 225-234 in D. A. Dixon, editor. Biology, management, and protection of catadromous eels. American Fisheries Society, Symposium 33, Bethesda, Maryland.

Vøllestad, L. A. 1992. The geographic variation in age and length at metamorphosis of maturing European eel: environmental effects and phenotypic plasticity. Journal of Animal Ecology 61:41-48.

Wenner, C. A. 1973. Occurrence of American eels, Anguilla rostrata, in waters overlying the eastern North American continental shelf. Journal of the Fisheries Research Board of Canada 30:1752-1755.

Wenner, C. A., and J. A. Musick. 1974. Fecundity and gonad observations of the American eel, Anguilla rostrata, migrating from Chesapeake Bay, Virginia. Journal of the Fisheries Research Board of Canada 31:1387-1391. 